\title{
A High-Throughput Molecular Pipeline Reveals the Diversity in Prevalence and Abundance of Pratylenchus and Meloidogyne Species in Coffee Plantations
}

\author{
Christopher A. Bell, Howard J. Atkinson, Alan C. Andrade, Hoa X. Nguyen, I. Gede Swibawa, \\ Catherine J. Lilley, James McCarthy, and P. E. Urwin ${ }^{\dagger}$
}

First, second, sixth, and eighth authors: Faculty of Biological Sciences, University of Leeds, Leeds, United Kingdom; third author: Embrapa Café/Inovacafé, Lavras, Brazil; fourth author: WASI, Buon Ma Thuot, Vietnam; fifth author: UNILA, Bandar Lampung, Indonesia; and seventh author: Nestle R.D. Tours, France.

Accepted for publication 27 December 2017.

\begin{abstract}
Coffee yields are adversely affected by plant-parasitic nematodes and the pathogens are largely underreported because a simple and reliable identification method is not available. We describe a polymerase chain reaction-based approach to rapidly detect and quantify the major Pratylenchus and Meloidogyne nematode species that are capable of parasitizing coffee. The procedure was applied to soil samples obtained from a number of coffee farms in Brazil, Vietnam, and Indonesia to assess the prevalence of these species associated both with coffee (Coffea arabica and C. canephora) and its intercropped species Musa acuminata (banana) and Piper nigrum (black pepper). Pratylenchus coffeae and P. brachyurus were associated with coffee in all three countries but there were distinct profiles of Meloidogyne spp. Meloidogyne incognita, M. exigua, and M. paranaensis were identified in

samples from Brazil and M. incognita and M. hapla were detected around the roots of coffee in Vietnam. No Meloidogyne spp. were detected in samples from Indonesia. There was a high abundance of Meloidogyne spp. in soil samples in which Pratylenchus spp. were low or not detected, suggesting that the success of one genus may deter another. Meloidogyne spp. in Vietnam and Pratylenchus spp. in Indonesia were more numerous around intercropped plants than in association with coffee. The data suggest a widespread but differential nematode problem associated with coffee production across the regions studied. The issue is compounded by the current choice of intercrops that support large nematode populations. Wider application of the approach would elucidate the true global scale of the nematode problem and the cost to coffee production.
\end{abstract}

Nematodes are very abundant in soils and many are pathogens of belowground plant tissue (Groombridge 1992; Hunt et al. 2005). Their pathogenicity affects many physiological processes of plants that can result in the reduction of aboveground yields, such as in Coffea spp. (Barbosa et al. 2004). Nematodes reduce global production of the economically important Coffea arabica and C. canephora species by approximately 15\% (Campos et al. 1990). Several Meloidogyne and Pratylenchus spp. cause damage throughout the main coffee-producing regions of Brazil, Central America, Columbia, Vietnam, and Indonesia (Carneiro et al. 2004; Gaitan and Cortina 2008; Trinh et al. 2009; Villain et al. 2013; Wiryadiputra 2008).

Pratylenchus and Meloidogyne are two of the most economically important plant-parasitic nematode genera of global agriculture (Jones et al. 2013). All juvenile and adult Pratylenchus nematodes are migratory and can enter and leave roots. They feed on plant cytosol during intracellular migration, leading to destruction of root tissue and promotion of secondary infection by other pathogens. Females lay eggs inside the root or in adjacent soil (Jones and FosuNyarko 2014). Second-stage juveniles of Meloidogyne invade host roots, establish a feeding site, and become sedentary. Most species are parthenogenetic and females become committed to a feeding site from which they utilize host resources. Species of both genera parasitize many crops globally (Trudgill and Blok 2001). Virulence of Meloidogyne spp. to coffee plants varies and thereby modulates

†Corresponding author: P. E. Urwin; E-mail: p.e.urwin@leeds.ac.uk

Funding: BBSRC for a Biosciences KTN CASE Studentship and financial support from Nestlé S.A. to C. A. Bell.

Copyright $@ 2018$ The Author(s). This is an open access article distributed under the CC BY 4.0 International license. the extent of yield loss and can sometimes result in plant death (Bertrand 2008). Meloidogyne and Pratylenchus spp. can coexist on the same coffee plant, possibly increasing the damage potential and the economic impact on the plantation (Herve et al. 2005).

Intercropping systems are common throughout coffee production and have many benefits to the grower (Jassogne et al. 2013). Two commonly grown intercrop plants are banana and black pepper but both are susceptible to nematode species that damage coffee (Gowen et al. 2005; Thuy et al. 2012). The impact of these hosts on nematode diversity in coffee fields is previously unexplored and increases the complexity of coffee nematode management. Accurate diagnosis of nematode prevalence and distribution in the soil of a plantation is important for pest management and will underpin future control efforts.

Identification of economic nematodes in a coffee plantation involves detection and estimating population numbers relative to damage thresholds. The latter requirement is made more complex by the aggregated distribution of Pratylenchus and Meloidogyne spp. in soil around coffee plants (Herve et al. 2005). Nematode identification commonly requires examination of many individual nematodes under a microscope and considerable taxonomic expertise is needed to identify and quantify the economic species of either Pratylenchus or Meloidogyne (Correa et al. 2013). This has been applied to identify multiple species of these two genera from coffee fields in several countries (Avelino et al. 2009; Carneiro et al. 1996, 2004; Mekete et al. 2008; Trinh et al. 2009). Polymerase chain reaction (PCR)-based identification has been proposed to overcome these difficulties (Berry et al. 2008; Correa et al. 2013, 2014; Machado et al. 2007; Toyota et al. 2008). Very little assessment of these molecular methods for diagnosis of Pratylenchus or Meloidogyne spp. in coffee fields has been reported (Carneiro et al. 2004, 2005; Sirias and Cristina 2011). A rapid, reliable, and sensitive method for assessing 
the plant-parasitic nematode community would enable greater understanding of the soil fauna and highlight the major species of concern, not just for coffee but for the entire farm.

We report the development of a molecular pipeline that combines novel with previously reported primer sets to identify and quantify nematodes extracted from soil surrounding coffee plants and its intercrops. A main aim was to identify the complex of species of Pratylenchus and Meloidogyne present in the soil rather than a single species. The procedures were designed to require neither specialized equipment for nematode extraction nor taxonomic expertise, thus underpinning the potential for widespread adoption by extension workers. The approach was then evaluated for exemplar fields in Brazil, Vietnam, and Indonesia. We report the occurrence and abundance of each species detected on coffee, banana, and black pepper and discuss the implications of the intercropping strategy.

\section{MATERIALS AND METHODS}

Field sampling, nematode extraction, and DNA preparation. Soil samples were taken from 6 coffee fields in Minas Gerais, Brazil; 14 coffee fields in Dak Lak, Vietnam; and 8 coffee fields in Lampung, Sumatra, Indonesia. In Brazil, 71 samples were obtained from soil surrounding the roots of coffee plants in monoculture plantations. In Vietnam, samples were obtained from soil around the upper roots of coffee $(n=82)$ plus those of two intercrops: black pepper $(n=40)$ and banana $(n=10)$. Similarly, in Indonesia, soil samples were taken from around coffee $(n=42)$, black pepper $(n=$ $7)$, and banana $(n=23)$. Each individual sample consisted of three soil cores ( $30 \mathrm{~cm}$ deep by $2.5 \mathrm{~cm}$ in diameter) that were taken from halfway between the stem and edge of the canopy of a single plant and pooled into one bag (Manzanilla-Lopez 2012). The main aim was to detect nematode presence; therefore, plants that showed signs of damage from some cause were selected where available (ManzanillaLopez 2012). Nematodes were extracted from $100 \mathrm{~g}$ of the soil sample using the method of Whitehead and Hemming (1965), as used before for populations of Pratylenchus and Meloidogyne from field soils (Bell and Watson 2001; Rodriguez-Kabana and Pope 1981; Wang and McSorley 2008; Yan et al. 2012). Soil was spread across a single layer of paper tissue that was supported in a wire basket. This was placed inside a plastic tray and water was added until the soil was damp but not waterlogged. Water containing nematodes was collected from the tray after $24 \mathrm{~h}$. Nematodes were recovered using a $25-\mu \mathrm{m}$ sieve and concentrated by centrifugation at $3,000 \times g$ for 3 min or by leaving the sample to settle overnight. The nematode pellet was resuspended in $100 \mu \mathrm{l}$ of lysis buffer $(100 \mathrm{mM} \mathrm{NaCl}$, $10 \mathrm{mM}$ Tris [pH 8], $10 \mathrm{mM}$ EDTA, $1 \%$ sodium dodecyl sulfate, $1 \%$ $\beta$-mercaptoethanol, and proteinase $\mathrm{K}$ at $100 \mu \mathrm{g} \mathrm{ml}^{-1}$ ), then incubated at $-20^{\circ} \mathrm{C}$ for at least $30 \mathrm{~min}, 60^{\circ} \mathrm{C}$ for $1 \mathrm{~h}$, and $90^{\circ} \mathrm{C}$ for $10 \mathrm{~min}$ to lyse cells and release DNA (Adam et al. 2007).

Specificity testing of diagnostic PCR primer sets and application to field samples. Primer sets for identification of several Pratylenchus and Meloidogyne spp. were obtained from

TABLE 1. Primer sequences used for the identification (ID) and quantification (Q) of Pratylenchus and Meloidogyne spp., alongside the annealing temperatures, product sizes, and sources

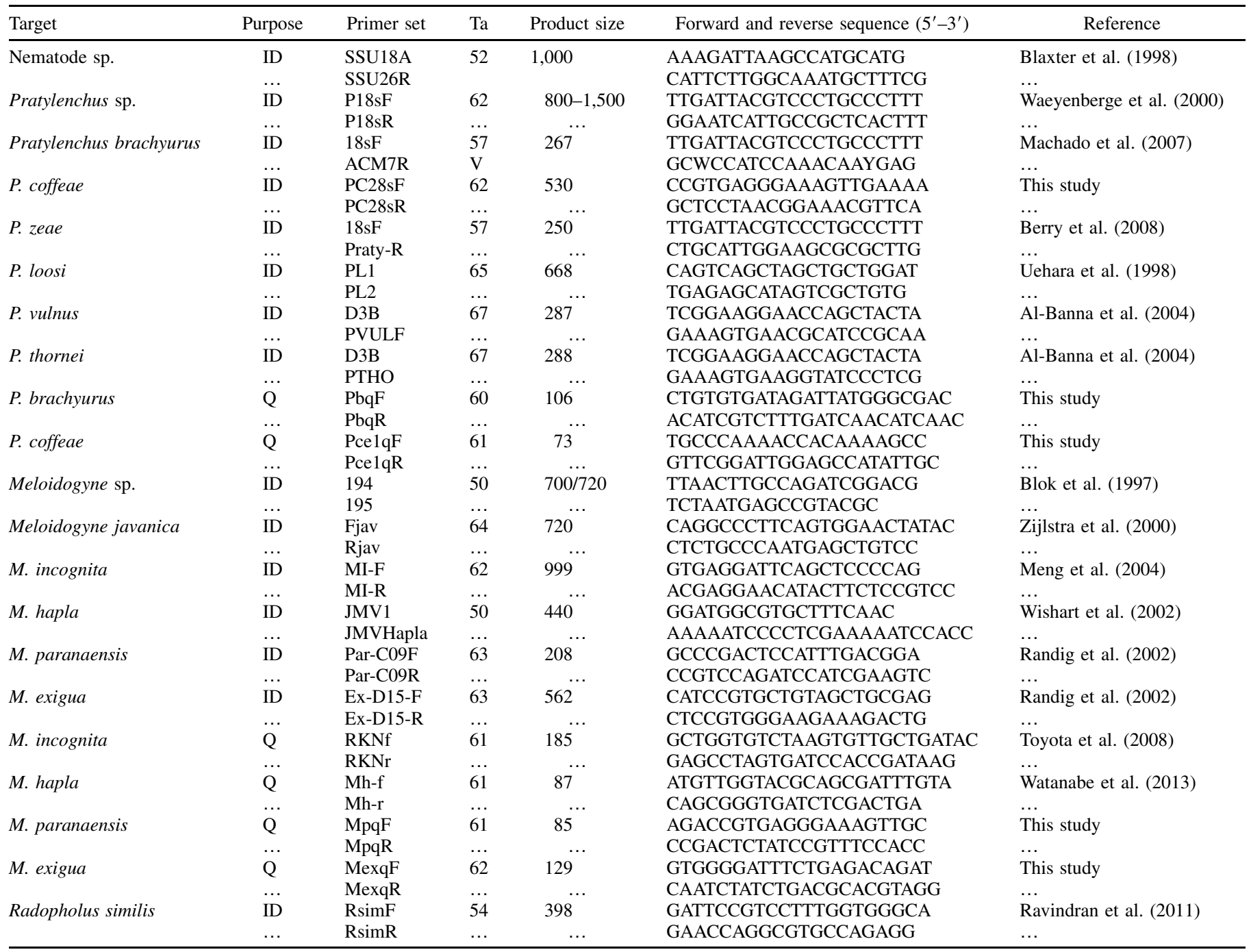


published sources (Table 1) and tested for specificity through PCR screening with target and nontarget DNA. Template DNA was extracted as above from a range of reference nematode populations: Pratylenchus coffeae (populations from Ghana, Guatemala, Japan, and Uganda), P. brachyurus (United States), P. zeae, P. vulnus (United States), P. loosi (Japan), P. thornei (United States), Meloidogyne exigua (Brazil), M. paranaensis (Brazil), M. incognita (Brazil), M. hapla, M. javanica (Turkey), and Radopholus similis (Uganda). This DNA was used in PCR with MyTaq polymerase (Bioline) according to the manufacturer's instructions and under the following conditions: $94^{\circ} \mathrm{C}$ for $60 \mathrm{~s}$ and 40 cycles of $94^{\circ} \mathrm{C}$ for $10 \mathrm{~s}, \mathrm{X}^{\circ} \mathrm{C}^{*}$ for $30 \mathrm{~s}, 72^{\circ} \mathrm{C}$ for $30 \mathrm{~s}$ and $72^{\circ} \mathrm{C}$ for $5 \mathrm{~min}\left(\mathrm{X}^{\circ} \mathrm{C}^{*}\right.$ indicates specific annealing temperature for each primer pair) (Table 1). The results prompted the design of new species-specific primers for $P$. coffeae, PC28sF/PC28sR (Table 1), based upon 28S ribosomal DNA sequence data obtained from GenBank (accession number KY424281).

Generic nematode-specific primers (SSU18A and SSU26R) (Blaxter et al. 1998) (Table 1) were utilized in PCR as above with $1 \mu \mathrm{l}$ of each field sample DNA, and reaction products were visualized on a $1 \%$ agarose gel to determine the success of nematode DNA extraction from soil samples. Genus-specific primer sets (Blok et al. 1997; Waeyenberge et al. 2000) were then used to identify the presence of Pratylenchus or Meloidogyne spp. within a sample. Species-specific primer sets then detected the presence of $P$. brachyurus (Machado et al. 2007), P. coffeae, P. zeae (Berry et al. 2008), P. loosi
(Uehara et al. 1998), P. vulnus (Al-Banna et al. 2004), P. thornei (Al-Banna et al. 2004), M. javanica (Zijlstra et al. 2000), M. incognita (Meng 2004; Meng et al. 2004), M. hapla (Wishart et al. 2002), M. paranaensis (Randig et al. 2002), M. exigua (Randig et al. 2002), or R. similis (Ravindran et al. 2011), another economically important nematode for coffee.

Specificity testing of quantitative PCR primer sets and quantification of nematodes. Quantitative PCR (qPCR) primer pairs RKNf/r (Toyota et al. 2008) and Mh-f/r (Watanabe et al. 2013) were confirmed to be specific for $M$. incognita and M. hapla, respectively. Primer pairs were designed to be specific for $P$. brachyurus $(\mathrm{PbqF} / \mathrm{R})$, P. coffeae (PcelqF/R), M. exigua (MeqF/R), and M. paranaensis (MpqF/ $\mathrm{R})$ based upon sequences present in GenBank (accession numbers KF537388.1, EU176871, AF435796, and AF435798, respectively). DNA was extracted from triplicate batches of 200, 100, 50, 20, and 5 individuals from each nematode species, as described above. These were used as standards in qPCR using SsoAdvanced Universal SYBR Green Supermix (Bio-Rad) to construct calibration curves of nematode number versus cycle threshold $\left(\mathrm{C}_{\mathrm{t}}\right)$ values. $\mathrm{qPCR}$ with species-specific primer sets was then applied to each field sample DNA with three technical replicates to obtain sample $C_{t}$ values. These $C_{t}$ values were aligned to the calibration curve to obtain an estimate of nematode number per sample.

Data analysis. Data were analyzed using a $t$ test and one-way analysis of variance (ANOVA) for comparison of two and three means, respectively, in SPSS (SPSS v24; IBM Corporation).

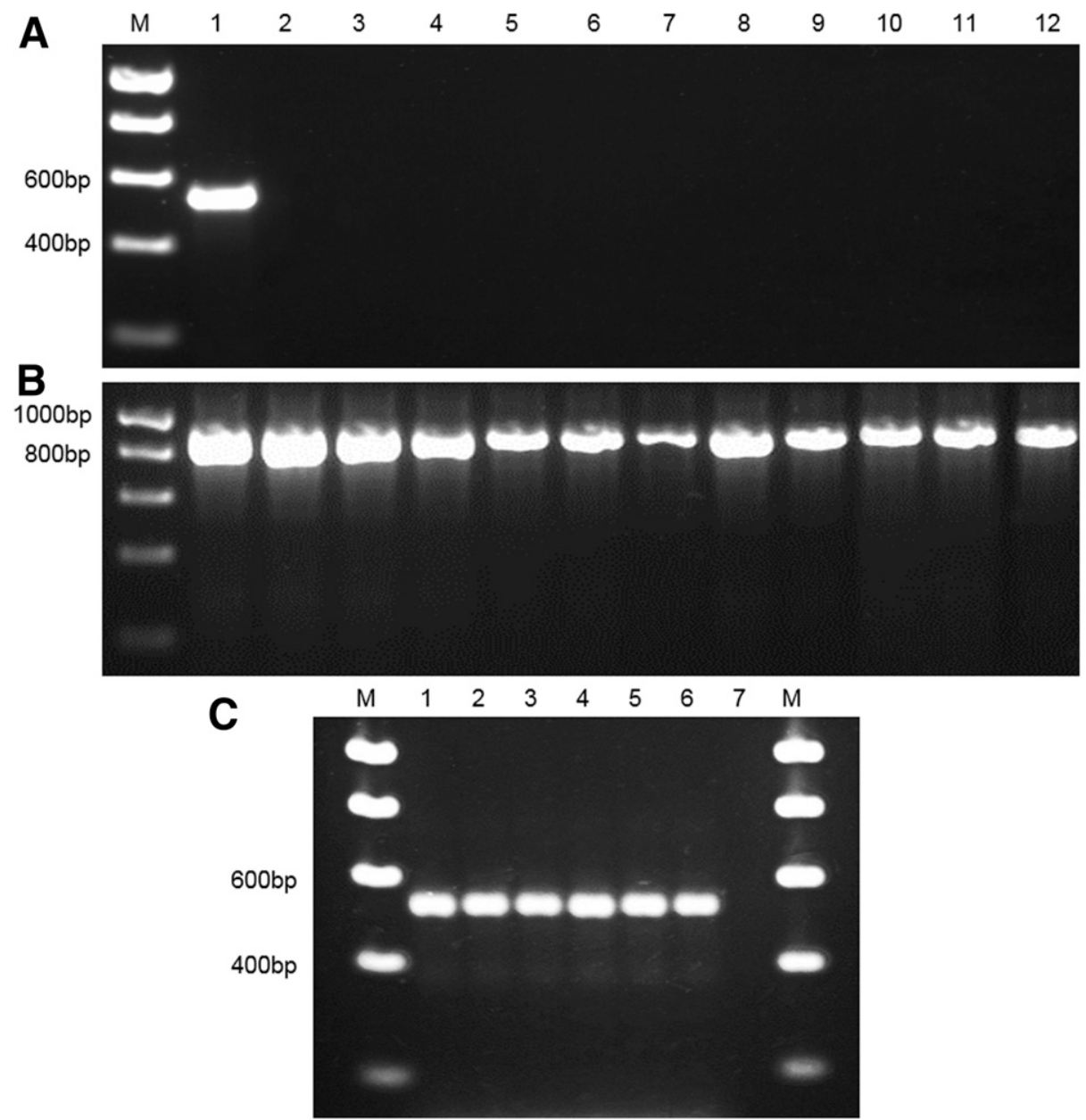

Fig. 1. Testing of primers specific to Pratylenchus coffeae. A, Specificity test of primers PC28sF and PC28sR on DNA derived from different nematode species: P. coffeae (lane 1), P. brachyurus (lane 2), P. zeae (lane 3), P. vulnus (lane 4), P. loosi (lane 5), P. thornei (lane 6), Meloidogyne exigua (lane 7), M. paranaensis (lane 8), M. incognita (lane 9), M. hapla (lane 10), M. javanica (lane 11), and Radopholus similis (lane 12). B, Quality of DNA from these species was confirmed through polymerase chain reaction with nematode $18 \mathrm{~S}$ primers (same lane labels as in A). C, PC28sF and PC28sR were tested on DNA from six populations of P. coffeae that were recovered from different hosts and locations: taro, Japan (lane 1); sweet potato, Japan (lane 2); coffee, Guatemala (lane 3); coffee, Guatemala (lane 4); coffee, Uganda (lane 5); and unknown host, Ghana (lane 6). Lane 7 is the no-template control and lane M signifies HyperLadder (1 kb). 
Correlations were determined using correspondence analysis in SPSS.

\section{RESULTS}

Extraction and primer specificity tests. The Whitehead and Hemming (1965) tray extraction method yielded vermiform nematodes from soil samples in $24 \mathrm{~h}$. Following lysis steps, these samples were then used immediately for identification. The specificity of new primers to $P$. coffeae (PC28sF and PC28sR) (Table 1) was confirmed when tested with template DNA from reference populations of P. coffeae, $P$. brachyurus, $P$. zeae, $P$. vulnus, $P$. loosi, $P$. thornei, M. exigua, $M$. paranaensis, $M$. incognita, $M$. hapla, $M$. javanica, and
$R$. similis. This primer set amplified a 530-bp PCR product from P. coffeae DNA with no amplification for any other species tested (Fig. 1A). The quality of the DNA from the nontarget species was confirmed through PCR with generic nematode $18 \mathrm{~S}$ primers (Fig. 1B). The broad utility of the primer set was verified following amplification of the species-specific product from DNA of six different $P$. coffeae populations from diverse geographic locations and multiple hosts (Fig. 1C).

Nematode detection in field samples. Presence of a speciesspecific PCR product established the detection of the plant-parasitic nematode species within the samples. The following results should not be interpreted as reflecting nationwide status of each nematode although, for simplicity, values are identified below by their country

TABLE 2. Pratylenchus and Meloidogyne spp. detected in soil surrounding coffee (C), black pepper (BP), and banana (B) crops in the 28 fields sampled

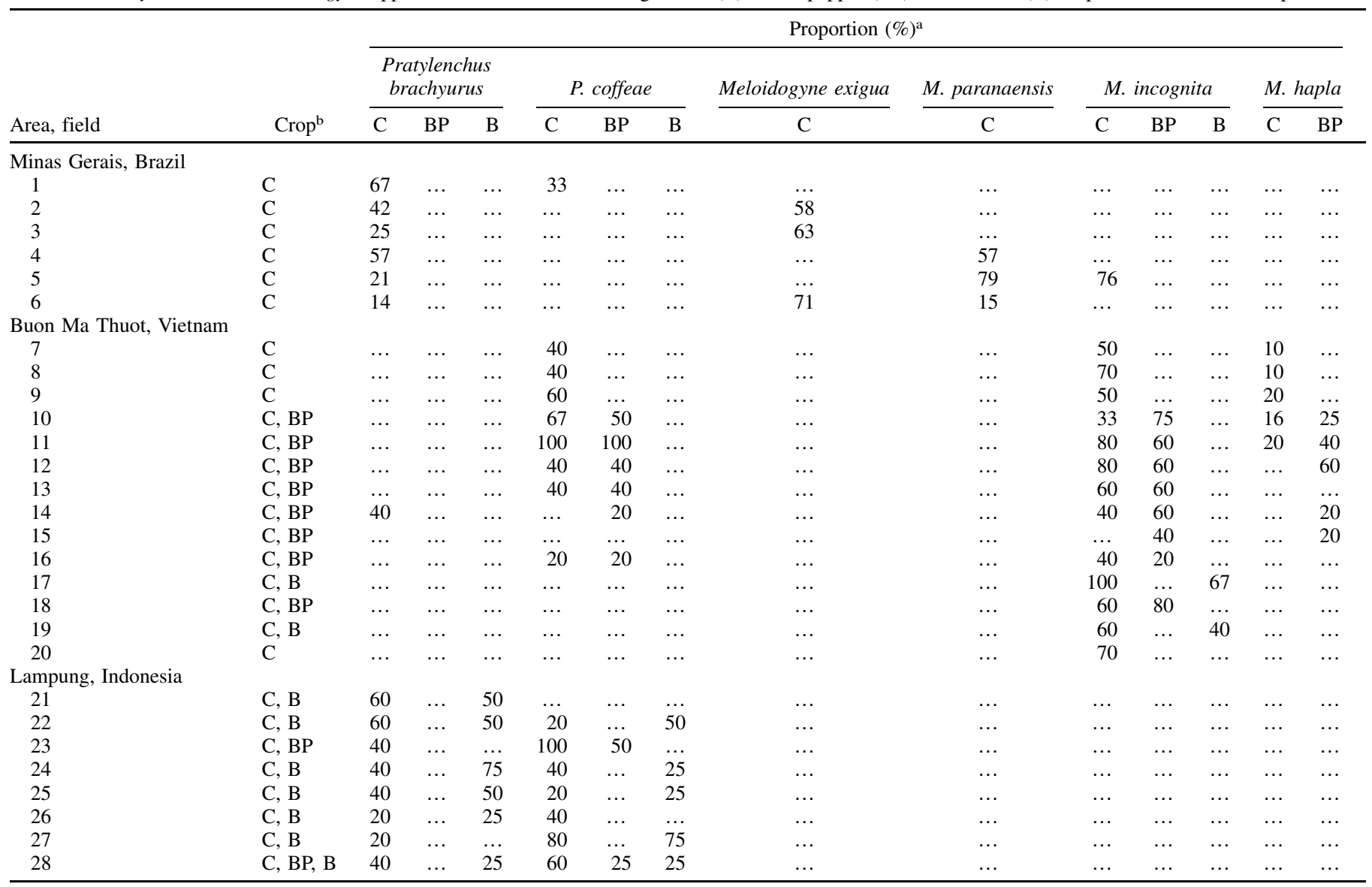

a Percentage values indicate the proportion of field crop samples that yielded positive detection for the species.

b Types of crops sampled.

TABLE 3. Percentage of total samples obtained from soil around the roots of coffee, black pepper, and banana in Minas Gerais (Brazil), Buon Ma Thuot (Vietnam), and Lampung (Indonesia) that contained each nematode species

\begin{tabular}{|c|c|c|c|c|c|c|c|c|}
\hline \multirow[b]{2}{*}{ Country, crop sampled } & \multirow[b]{2}{*}{ Total $^{\mathrm{a}}$} & \multicolumn{7}{|c|}{ Samples with nematode detected $(\%)$} \\
\hline & & Pratylenchus brachyurus & P. coffeae & Meloidogyne exigua & M. paranaensis & M. incognita & M. hapla & Any ${ }^{b}$ \\
\hline \multicolumn{9}{|l|}{ Brazil } \\
\hline \multicolumn{9}{|l|}{ Vietnam } \\
\hline Coffee & 82 & 2 & 23 & 0 & 0 & 53 & 8 & 56 \\
\hline Black pepper & 40 & 0 & 35 & 0 & 0 & 53 & 18 & 61 \\
\hline Banana & 10 & 0 & 0 & 0 & 0 & 60 & 0 & 60 \\
\hline \multicolumn{9}{|l|}{ Indonesia } \\
\hline Black pepper & 7 & 0 & 29 & 0 & 0 & 0 & 0 & 29 \\
\hline Banana & 23 & 26 & 35 & 0 & 0 & 0 & 0 & 65 \\
\hline
\end{tabular}

a Number of total crops sampled.

b Any of the six species detected. 
of origin. In total, two Pratylenchus spp. and four Meloidogyne spp. were detected in soil samples from Brazil, Vietnam, and Indonesia (Table 2). P. brachyurus and P. coffeae were detected in all three countries from soil surrounding coffee as well as the intercrops of black pepper and banana. Pratylenchus spp. were detected in six fields in Brazil which were monocultures of coffee plants. M. exigua, $M$. paranaensis, and $M$. incognita were detected in samples from the coffee plantations in Brazil whereas M. incognita and M. hapla were identified in Vietnam from soil surrounding the roots of coffee and black pepper. Nematodes of both genera occurred in 5 of the 6 Brazilian fields and 9 of the 14 Vietnamese fields. No Meloidogyne spp. were detected in samples from the Indonesian coffee fields.

Plant-parasitic nematodes from the genera Meloidogyne and Pratylenchus were detected in $75 \%$ of the total samples obtained from coffee fields in Minas Gerais, Brazil (Table 3). P. brachyurus was present in more samples than P. coffeae (37 and 7\%, respectively). The frequency of detection for M. exigua, M. paranaensis, and M. incognita was 35,27 , and $17 \%$ of samples, respectively. $P$. coffeae was the more frequently detected species of that genus in Buon Ma Thuot, Vietnam and detected in 23 and $35 \%$ of samples taken from soil around coffee and black pepper, respectively. $M$. incognita was detected in 53,53, and $60 \%$ of soil samples associated with coffee, black pepper, and banana, respectively (Table 3 ). P. brachyurus and $P$. coffeae were present in 32 and $34 \%$ of samples from coffee in Indonesia and 26 and 35\% of samples from banana, respectively. For black pepper, P. coffeae occurred in $29 \%$ of soil samples but $P$. brachyurus was not detected. Another economic nematode, $R$. similis, was not detected in any sample from the three countries.

Evaluation of quantification primers. All primer sets were confirmed to be specific to the reference populations of the target species by qPCR using DNA from target and nontarget nematodes. The latter were the same species used in previous primer testing. Calibration curves were generated from the $C_{t}$ values of standards made from known numbers of nematodes (Fig. 2). These displayed the expected negative correlation between $C_{t}$ value and the number of nematodes ( $R^{2}>0.97$ for all primer sets). This provided the linear calibration from which the numbers of nematodes are established below.

Quantification of plant-parasitic nematode species in field samples. Pratylenchus spp. were detected in only $44 \%$ of 71 samples obtained in Brazil but in the range of 54 to 482 individuals per $100 \mathrm{~g}$ of soil per sample when present (Fig. 3A). In fields in Vietnam, the nematode was detected in only $25 \%$ of the 82 samples from soil around coffee roots but, when present, ranged from 15 to 102 individuals per $100 \mathrm{~g}$ of soil. In Indonesia, Pratylenchus spp. were detected in $63 \%$ of the 43 samples from soil around coffee roots in the range of 19 to 493 individuals per $100 \mathrm{~g}$ of soil. One or more Meloidogyne spp. were present in $69 \%$ of samples for the five Brazilian fields in which the genus was recorded at a range of 11 to 529 Meloidogyne per $100 \mathrm{~g}$ of soil (Fig. 3B). Only M. incognita and M. hapla were detected in Vietnam, with a prevalence of $58 \%$ of samples obtained from coffee in the range of 14 to 274 Meloidogyne per $100 \mathrm{~g}$ of soil.

In samples from the three countries, the mean population densities of detected species in soil around coffee plants were considerably greater than previously suggested damage thresholds for P. brachyurus $(n=0)$, . coffeae $(n=0)$, M. exigua $(n=25)$, and M. incognita $(n=200)$ on coffee (Oliveira et al. 1999; Rodrigues and Crozzoli 1995; Trinh et al. 2011; Vovlas and Di Vito 1991) (Fig. 4). The densities of both Pratylenchus spp. were higher on coffee in Brazil than Vietnam or Indonesia $(P<0.05, t$ test $)$. Both Pratylenchus spp. were similarly abundant in the sampled fields in Brazil and Vietnam; however, $P$. coffeae was more numerous than $P$. brachyurus in Indonesian fields ( $P<0.05$, one-way ANOVA). $M$. incognita was more abundant than $M$. hapla in samples obtained from coffee $(P<0.01, t$ test $)$. Nematode populations were at higher densities in soil associated with black pepper and banana plants than coffee in both Vietnam and Indonesia (Fig. 4) $(P<0.05, t$ test and one-way ANOVA for comparison of two and three means, respectively).

The relationship between Pratylenchus and Meloidogyne spp. abundance in soil samples. There was a significant negative correlation between numbers of Pratylenchus and Meloidogyne spp. for 96 samples associated with coffee or black pepper for fields in which both genera were detected $(R=-0.225 ; P<0.05$, twotailed test). The relationship was examined further using correspondence analysis and a significant summary $\chi^{2}(23.5, P<0.001)$ was obtained. The resultant biplot represents $24 \%$ of the variation in the data with most of that value (21\%) represented by the horizontal axis of the graph. Therefore, the plot suggests that, in fields where both genera were detected, there is an association of high numbers of Meloidogyne spp. where Pratylenchus spp. were not detected. This is indicated by the proximity of the relevant data points in the horizontal axis $\left(\mathrm{M}_{\mathrm{h}}\right.$ and $\left.\mathrm{P}_{\mathrm{nd}}\right)$ (Fig. 5).
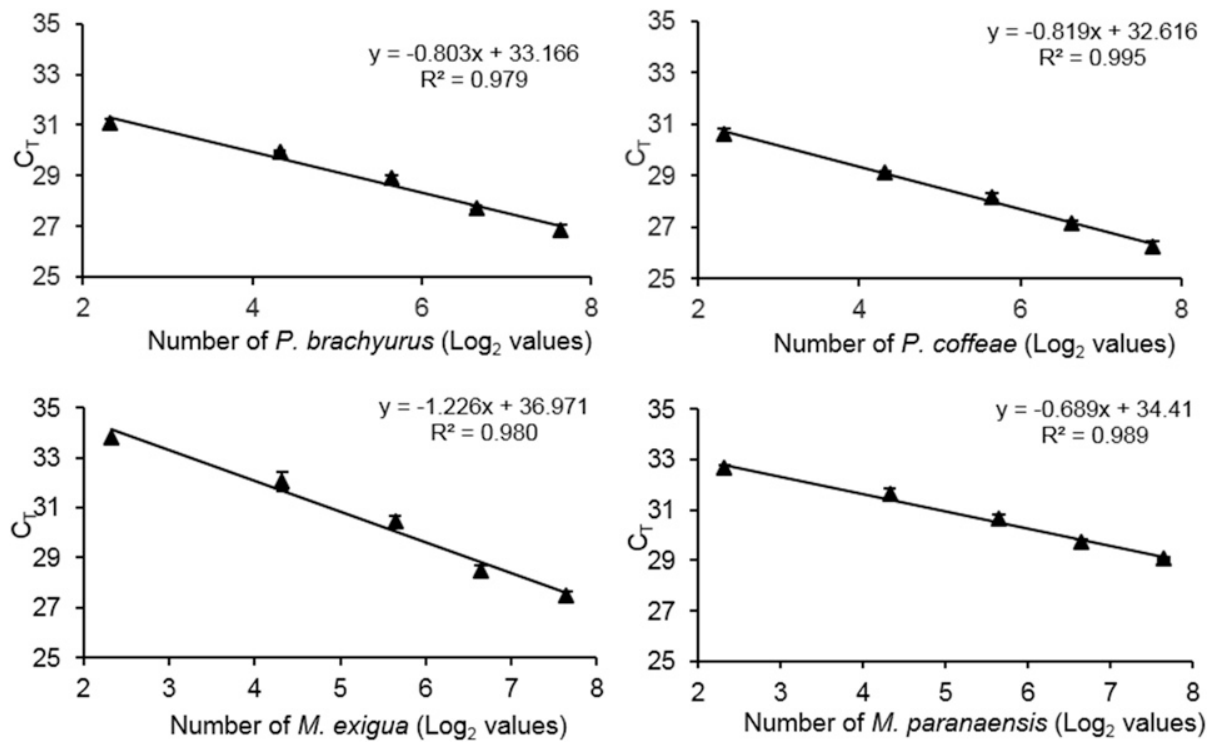

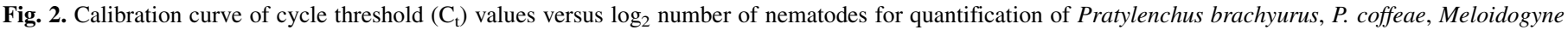

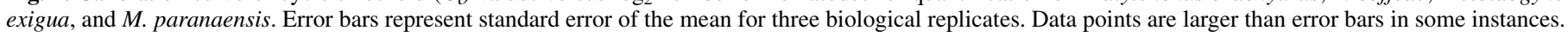




\section{DISCUSSION}

Here, we demonstrate a molecular pipeline for rapid identification and estimation of soil populations of Pratylenchus and Meloidogyne nematode species that commonly damage coffee crops. This is the first molecular-based study to assess the plant-parasitic nematode community within coffee fields by sampling multiple crop plants in three major coffee-producing countries.

This study confirmed the ability of the Whitehead and Hemming tray method to extract high numbers of mobile Pratylenchus and Meloidogyne nematodes from soil (Rodriguez-Kabana and Pope 1981). Nematode extraction required minimal preparation time and equipment and the lysis method for DNA extraction provided sufficient extract for approximately 100 reactions and avoided the time-consuming DNA preparations of much previous work (Adam et al. 2007; Castagnone-Sereno et al. 1995; Stanton et al. 1998). The assay revealed that $P$. brachyurus and $P$. coffeae were similarly abundant in Brazil whereas $P$. coffeae was the more numerous species of the genus in Indonesia. Both of these species are known pathogens of coffee in these countries and can cause great damage to coffee roots and result in reduced plant growth (Oliveira et al. 1999; Trinh et al. 2011; Wiryadiputra 2008). This study detected M. exigua and M. paranaensis in Brazil, where they are widespread parasites of coffee plants (Barbosa et al. 2004; Carneiro et al. 1996; Muniz et al. 2008; Salgado et al. 2015). M. incognita was detected in both Brazil and Vietnam, where it is prevalent in coffee plantations (Carneiro et al. 2004; Trinh et al. 2009). This study reports the first detection of $M$. hapla in Vietnam, where it may have been previously identified as a different species or introduced through movement of cultivars. Although it has been reported in Hawaii, Guatemala, El Salvador, Brazil, India, and several countries in Africa, the species is not widespread in coffee plantations (Campos and Villain 2005; Handoo et al. 2005; Lordello 1982; Villain et al. 2013). Although the presence of any parasitic-nematode species capable of damaging coffee is of interest, $M$. hapla has not been reported as widespread and it results in relatively low damage to coffee roots (Villain et al. 2013). Consequently it may not represent as major a concern for the growers as some other species of this genus.

Genetically distinct populations of $M$. incognita, M. paranaensis, and M. exigua are present in Central and South America, suggesting

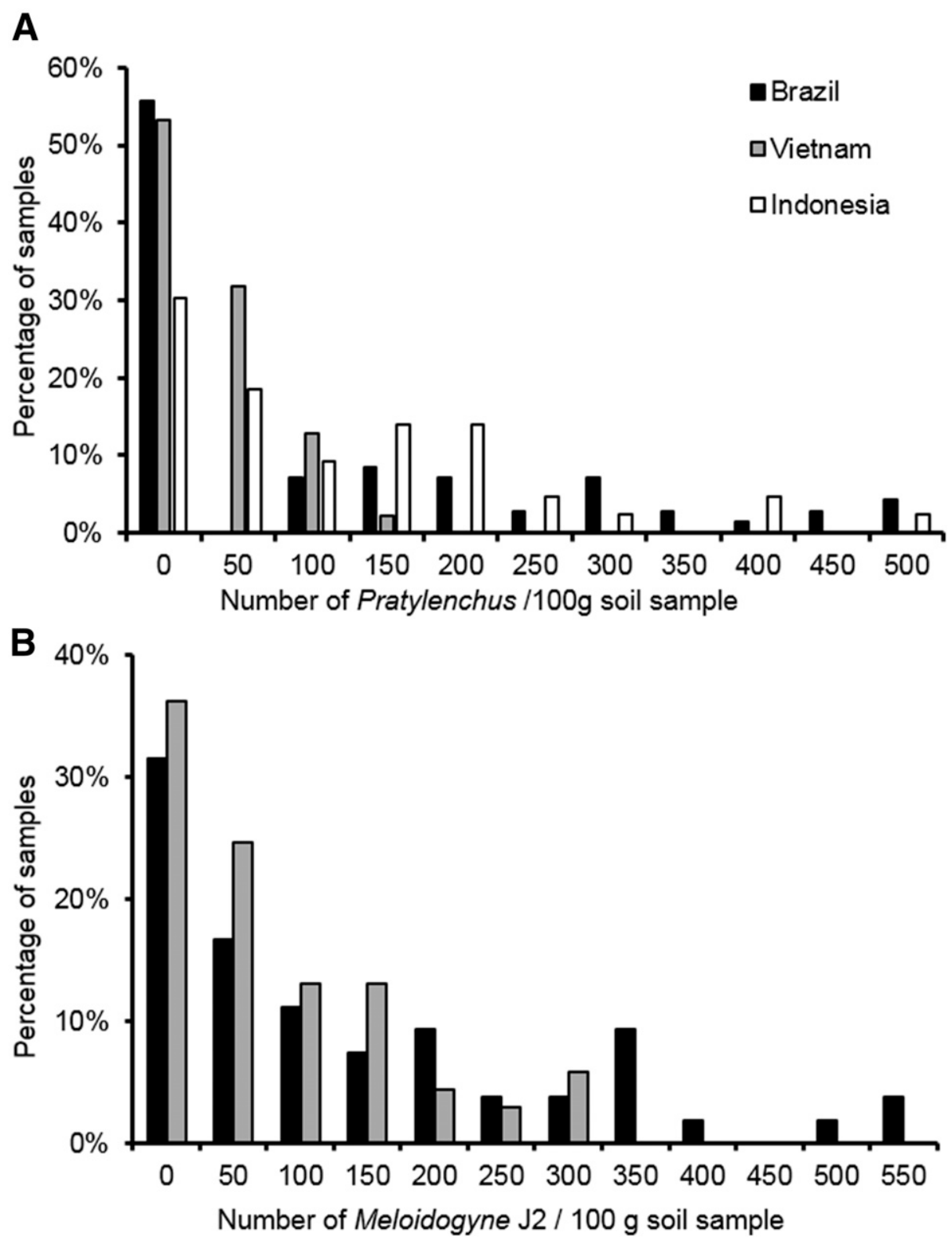

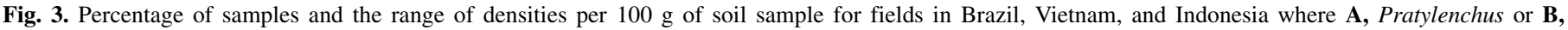
Meloidogyne nematodes were detected. Bar charts are based on 160 samples for Pratylenchus and 123 for Meloidogyne. 
that genetic divergence has resulted in multiple species types (Carneiro et al. 2004; Randig et al. 2002). The chances of false negatives due to genetic divergence is reduced because several primer sets used in this report have previously been applied to samples from widespread locations (Devran and Sogut 2009; Hu et al. 2011; Randig et al. 2002). Further molecular analysis could help elucidate the origins of populations detected in this study, map their distributions, and assist in developing management strategies based on resistant cultivars. No Meloidogyne spp. were detected for the Indonesian samples, which was unexpected, given the abundance of the genus in Brazilian and Vietnamese samples and its known wide international distribution and polyphagy. Presence of $M$. incognita has been reported on other crops in the country; therefore, it is of utmost importance that coffee fields are protected from introduction of the pathogen (Tuminem et al. 2015). The lack of Meloidogyne spp. may also be due to the less structured farming system observed in Indonesia, compared with fields sampled in Brazil and Vietnam (unpublished data). The irregular nature of planting may have had a negative impact on the establishment and spread of Meloidogyne spp. throughout a field, whereas this may not prove to be as important for Pratylenchus spp. that can migrate through soil at a greater rate than Meloidogyne second-stage juveniles (Nježić et al. 2014), thereby possibly allowing them to locate hosts at a greater distance.

The occurrence of the target nematodes in soils associated with intercrops at similar or higher densities than around coffee roots justifies reconsideration of appropriate crops to favor marginal or nonhosts. Furthermore, the greater abundance of several nematode species on the intercrop compared with the main crop raises the concern that an intercrop may not only be a suitable host but also
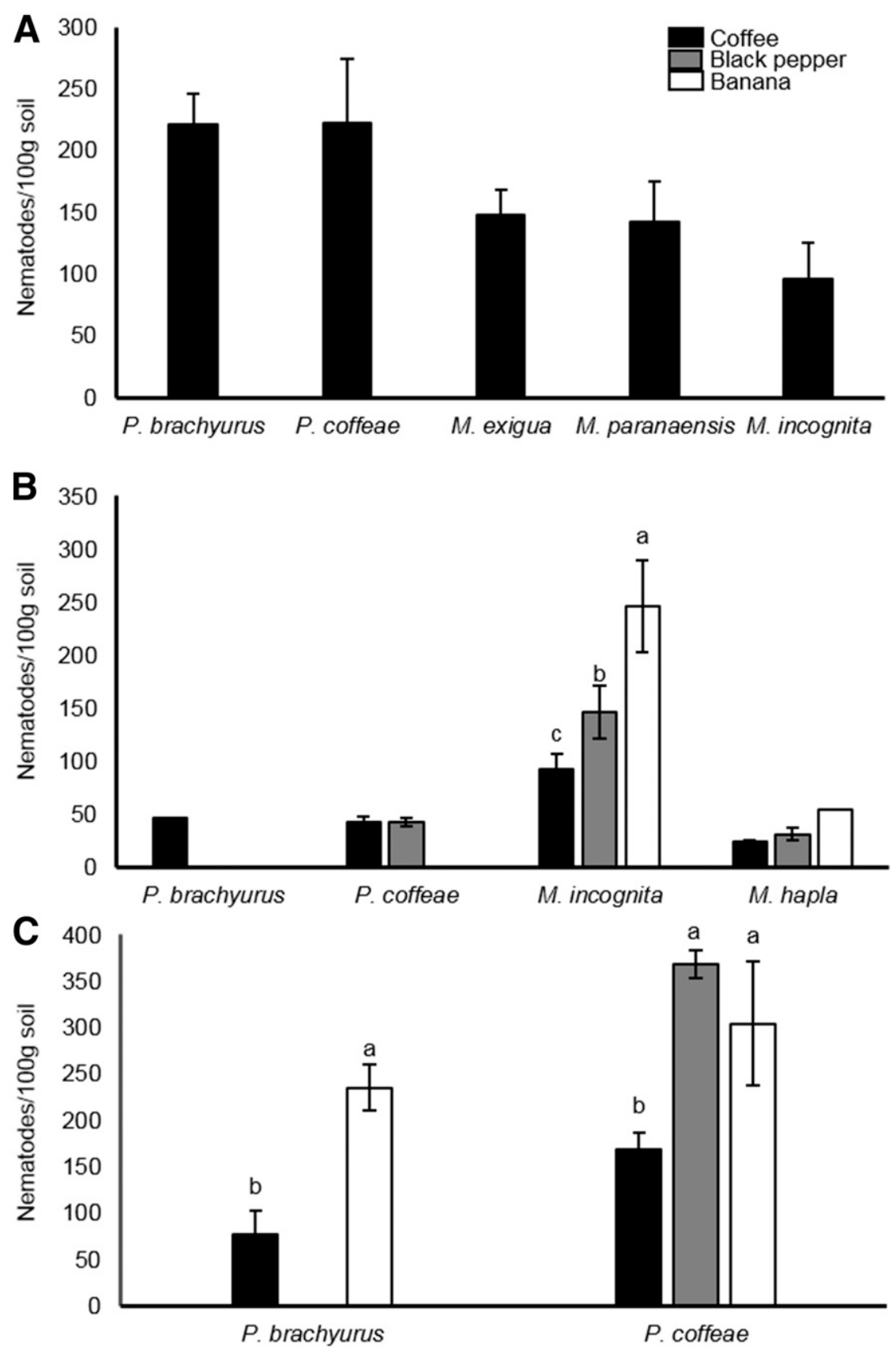

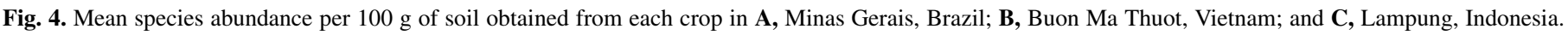

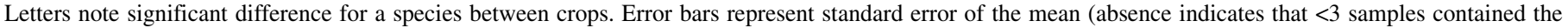
nematode species). 
provide tissue for nematode populations to increase in the field relative to densities associated with coffee plants. Predominance of $P$. coffeae in Vietnam may arise from conversion of fields from banana to coffee because both crops are hosts (Trinh et al. 2009). Currently, there is an increase in the cropping of black pepper within Brazilian coffee fields due to its drought tolerance and high value (Terazono 2017). This will influence the relative abundance of different nematodes present in the plantations, particularly because black pepper is not a known host for $P$. brachyurus and was also not indicated as such in this study.

The distribution of nematode field populations can frequently be described by negative binomial expression (Herve et al. 2005; Nyczepir 2009). A balance is needed between the time and cost of taking many samples against the risk of not detecting a population that is present. The negative binomial suggests that 10 samples per field, as in this study, will reliably record a population if extensive sampling established that $40 \%$ or more samples are expected to contain the target species. Therefore, our sampling strategy should reliably record the occurrence of a target species from a plantation. Sampling close to coffee plants that look damaged reduces the likelihood of reaching a false-negative conclusion and more extensive sampling could be considered if the population is not detected; however, confidence in that outcome is important.

Although several nematode species were detected within fields, there was an association of high numbers of Meloidogyne spp. in soil samples in which Pratylenchus spp. were low or not detected. Soil type, topography, and climatic factors have a differential effect on $P$. coffeae and M. exigua on coffee roots in Costa Rica (Avelino et al. 2009). That work also indicated competition between the two species in the roots of coffee plants, resulting in negative correlation between their populations. An association of high Meloidogyne spp. populations and low density of $P$. coffeae was also reported previously in the roots of coffee in Costa Rica using correspondence analysis (Herve et al. 2005). Previous work on peach, onion, mung bean, sugarcane, and barley roots has demonstrated competition between

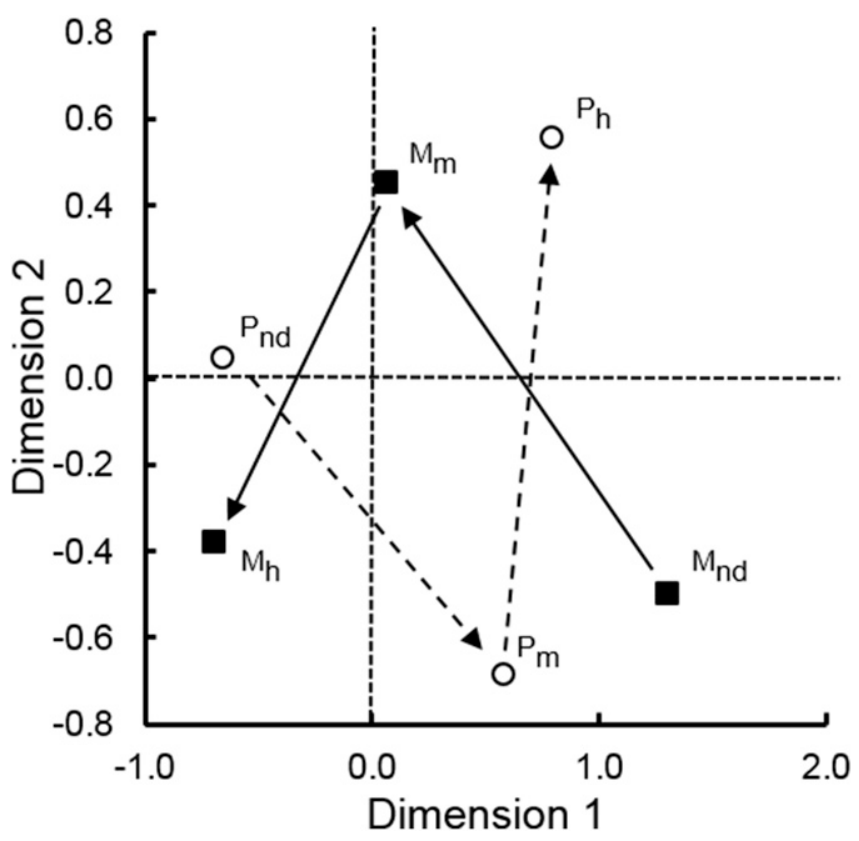

Fig. 5. Correspondence analysis showing association between Pratylenchus and Meloidogyne spp. on coffee or black pepper for 96 samples from fields in Brazil and Vietnam, in which both genera were detected. Association is indicated by proximity of data points for the three categories. Account should be taken of the relative contributions to the overall variation in the data that is explained in dimension $1(21.0 \%)$ and dimension 2 (3.7\%) of Pratylenchus $(\mathrm{P})$ and Meloidogyne (M) nematodes per $100 \mathrm{~g}$ of soil that were (i) not detected in a sample $\left(\mathrm{P}_{\mathrm{nd}}\right.$ and $\left.\mathrm{M}_{\mathrm{nd}}\right)$, (ii) moderate $\left(\mathrm{P}_{\mathrm{m}} 12-51\right.$ and $\mathrm{M}_{\mathrm{m}}$ 11-111), and (iii) high $\left(\mathrm{P}_{\mathrm{h}}\right.$ 52-486 and $\mathrm{M}_{\mathrm{h}}$ 112-529). both genera of nematode with the effect and scale of effect differing with the host (BieYun 2008; Fontana et al. 2015; Nyczepir 2009; Pang et al. 2009; Umesh et al. 1994). It is of interest that the competition is observed in samples from both Brazil and Vietnam in this study, indicating its importance in global coffee-farming systems. Intergeneric competition will affect the success of each species and, therefore, impact the entire nematode community with consequences on field output. Further analysis is required to determine the effects of coffee cultivars on the scale of competition.

The status of nematodes on coffee is often assessed by sampling roots, thereby disturbing the plants. However, assessments are also made on soil populations (Barros et al. 2014; Herrera et al. 2011; Trinh et al. 2012). Additionally, the presence of Pratylenchus spp. known to damage coffee is reason enough to initiate a management program without considering its population level (Villain 2008). Coffee growers should also be advised to remain vigilant for the presence of root-knot nematodes in their plantations (Campos and Silva 2008). The nondestructive approach taken in this work is more favorable to growers and, thus, may gain wide acceptance for routine screening for management decisions, particularly where crops with sensitive roots such as black pepper are grown.

Our soil sampling of established coffee plants indicated similar mean soil densities for $P$. brachyurus and $P$. coffeae on coffee in all three countries. Alarmingly, these densities are above the damage thresholds for these species on coffee, indicating that the crop is negatively affected by this genus. There is evidence that $M$. exigua in Brazil is severely damaging to coffee and the densities found in our samples reveal the frequent severity of infestations (Rodrigues and Crozzoli 1995). More work is required in Vietnam to determine how often populations of $M$. incognita and M. hapla damage coffee and the damage thresholds of species complexes in different environments. The current work provides a rapid approach that can be applied with support from any competent molecular laboratory and, therefore, enables inexpensive widespread evaluation for many coffee plantations. It indicates that Pratylenchus spp. may be widely damaging to coffee plantations whereas species of Meloidogyne have more limited distributions. Work is planned to relate results from the rapid estimation of soil populations to damage severity and thresholds for each nematode in a range of growing conditions. Additional primers could be designed to detect further species that occur in these countries but not in the regions sampled in this study, such as P. jaehni (Inserra et al. 2001). Alongside the work studied here, this will underpin global efforts to manage populations and support selection of appropriate resistant cultivars for different localities.

\section{ACKNOWLEDGMENTS}

We thank P. P. Ngoc, N. T. Tuong, and N. T. N. Hoa (Nestlé Vietnam), X. N. Hoa laboratory members (WASI Vietnam), A. Junda, M. A. Wicaksana, N. T. Sari, and Y. S. Ariza (Nestlé Indonesia), Lampung University UNILA (Indonesia), and S. M. L Salgado, J. P. Faz. Da Lagoa, and H. Faessler for assistance with the organization and collection of nematode samples; S. Canz and W. De Smet of Nestlé for supporting the work; and the suppliers of reference populations of Pratylenchus (P. Roberts, University of California, Riverside) and Meloidogyne (R. D. L. Oliveira, Viçosa Federal University, Brazil).

\section{LITERATURE CITED}

Adam, M. A. M., Phillips, M. S., and Blok, V. C. 2007. Molecular diagnostic key for identification of single juveniles of seven common and economically important species of root-knot nematode (Meloidogyne spp.). Plant Pathol. 56:190-197.

Al-Banna, L., Ploeg, A. T., Williamson, V. M., and Kaloshian, I. 2004. Discrimination of six Pratylenchus species using PCR and species-specific primers. J. Nematol. 36:142-146.

Avelino, J., Bouvret, M. E., Salazar, L., and Cilas, C. 2009. Relationships between agro-ecological factors and population densities of Meloidogyne exigua and Pratylenchus coffeae sensu lato in coffee roots, in Costa Rica. Appl. Soil Ecol. 43:95-105. 
Barbosa, D. H. S. G., Vieira, H. D., Souza, R. M., Viana, A. P., and Silva, C. P. 2004. Field estimates of coffee yield losses and damage threshold by Meloidogyne exigua. Nematol. Bras. 28:49-54.

Barros, A. F., Oliveira, R. D. L., Lima, I. M., Coutinho, R. R., Ferreira, A. O., and Costa, A. 2014. Root-knot nematodes, a growing problem for Conilon coffee in Espirito Santo state, Brazil. Crop Prot. 55:74-79.

Bell, N. L., and Watson, R. N. 2001. Optimising the Whitehead and Hemming tray method to extract plant parasitic and other nematodes from two soils under pasture. Nematology 3:179-185.

Berry, S. D., Fargette, M., Spaull, V. W., Morand, S., and Cadet, P. 2008. Detection and quantification of root-knot nematode (Meloidogyne javanica), lesion nematode (Pratylenchus zeae) and dagger nematode (Xiphinema elongatum) parasites of sugarcane using real-time PCR. Mol. Cell. Probes 22:168-176.

Bertrand, B. A. F. 2008. Genetics of resistance to root-knot nematodes (Meloidogyne spp.) and breeding. Pages 165-191 in: Plant-Parasitic Nematodes of Coffee. R. Souza, ed. Springer Science+Business Media B.V., Dordrecht

BieYun, T. 2008. Competition between Pratylenchus coffeae and Meloidogyne incognita. Plant Pathol. Bull. 17:271-278.

Blaxter, M. L., De Ley, P., Garey, J. R., Liu, L. X., Scheldeman, P., Vierstraete, A., Vanfleteren, J. R., Mackey, L. Y., Dorris, M., Frisse, L. M., Vida, J. T., and Thomas, W. K. 1998. A molecular evolutionary framework for the phylum Nematoda. Nature 392:71-75.

Blok, V. C., Phillips, M. S., and Fargette, M. 1997. Comparison of sequences from the ribosomal DNA intergenic region of Meloidogyne mayaguensis and other major tropical root-knot nematodes. J. Nematol. 29:16-22.

Campos, V. P., and Silva, J. R. C. 2008. Indonesia and Vietnam. Pages 149-164 in: Plant-Parasitic Nematodes of Coffee. R. Souza, ed. Springer Science+ Business Media B.V., Dordrecht.

Campos, V. P., Sivapalan, P., and Gnanapragasam, N. C. 1990. Nematode parasites of coffee, cocoa and tea. Pages 387-400 in: Plant-Parasitic Nematodes in Subtropical and Tropical Agriculture. M. Luc, R. A. Sikora, and J. Bridge, eds. CAB International, Wallingford, UK

Campos, V. P., and Villain, L. 2005. Nematode parasites of coffee and cocoa. Pages 529-580 In: Plant-Parasitic Nematodes in Subtropical and Tropical Agriculture. M. Luc, R. A. Sikora, and J. Bridge, eds. CAB International, Wallingford, UK.

Carneiro, R. M. D. G., Carneiro, R. G., Abrantes, I. M. O., Santos, M. S. N. A., and Almeida, M. R. A. 1996. Meloidogyne paranaensis n. sp. (Nemata: Meloidogynidae), a root-knot nematode parasitizing coffee in Brazil. J. Nematol. 28:177-189.

Carneiro, R. M. D. G., Randig, O., Almeida, M. R. A., and Goncalves, W. 2005. Identification and characterization of Meloidogyne species on coffee from Sao Paulo and Minas Gerais States of Brazil using esterase phenotypes and SCAR-PCR multiplex. Nematol. Bras. 29:233-241.

Carneiro, R. M. D. G., Tigano, M. S., Randig, O., Almeida, M. R. A., and Sarah, J.-L. 2004. Identification and genetic diversity of Meloidogyne spp. (Tylenchida: Meloidogynidae) on coffee from Brazil, Central America and Hawaii. Nematology 6:287-298.

Castagnone-Sereno, P., Esparrago, G., Abad, G., Leroy, F., and Bongiovanni, M. 1995. Satellite DNA as a target for PCR specific detection of the plantparasitic nematode Meloidogyne hapla. Curr. Genet. 28:566-570.

Correa, V. R., Dos Santos, M. F. A., Almeida, M. R. A., Peixoto, J. R., Castagnone-Sereno, P., and Carneiro, R. M. D. G. 2013. Species-specific DNA markers for identification of two root-knot nematodes of coffee: Meloidogyne arabicida and M. izalcoensis. Eur. J. Plant Pathol. 137:305-313.

Correa, V. R., Mattos, V. S., Almeida, M. R. A., Santos, M. F. A., Tigano, M. S., Castagnone-Sereno, P., and Carneiro, R. M. D. G. 2014. Genetic diversity of the root- knot nematode Meloidogyne ethiopica and development of a species-specific SCAR marker for its diagnosis. Plant Pathol. 63: 476-483.

Devran, Z., and Sogut, M. A. 2009. Distribution and identification of root-knot nematodes from Turkey. J. Nematol. 41:128-133.

Fontana, L. F., Dias-Arieira, C. R., Mattei, D., Severino Junior, J., Biela, F., and Arieira, J. de O. 2015. Competition between Pratylenchus zeae and Meloidogyne incognita on sugarcane. Nematropica 45:1-8.

Gaitan, A. R., and Cortina, C. H. 2008. Colombia. In: Plant-Parasitic Nematodes of Coffee. R. Souza, ed. Springer Science+Business Media B.V., Dordrecht.

Gowen, S. R., Queneherve, P., and Fogain, R. 2005. Nematode parasites of bananas and plantains. In: Plant-Parasitic Nematodes in Subtropical and Tropical Agriculture. M. Luc, R. A. Sikora, and J. Bridge, eds. CAB International, Wallingford, UK pages 611-645.

Groombridge, A. B. 1992. Global Biodiversity. Status of the Earth's Living Resources. Chapman \& Hall, London.

Handoo, Z. A., Skantar, A. M., Carta, L. K., and Schmitt, D. P. 2005. Morphological and molecular evaluation of a Meloidogyne hapla population damaging coffee (Coffea arabica) in Maul, Hawaii. J. Nematol. 37:136-145.
Herrera, I., Bryngelsson, T., and Monzon, A. 2011. Occurrence of Meloidogyne sp. and Pratylenchus sp. in conventional and organic coffee systems in Nicaragua. Nematropica 41:82-90.

Herve, G., Bertrand, B., Villain, L., Licardie, D., and Cilas, C. 2005. Distribution analyses of Meloidogyne spp. and Pratylenchus coffeae sensu lato in coffee plots in Costa Rica and Guatemala. Plant Pathol. 54: 471-475.

Hu, M. X., Zhuo, K., and Liao, J. L. 2011. Multiplex PCR for the simultaneous identification and detection of Meloidogyne incognita, M. enterolobii, and $M$. javanica using DNA extracted directly from individual galls. Phytopathology 101:1270-1277

Hunt, D. J., Luc, M., and Manzanilla-Lopez, R. 2005. Identification, morphology and biology of plant parasitic nematodes. In: Plant-Parasitic Nematodes in Subtropical and Tropical Agriculture. M. Luc, R. A. Sikora, and J. Bridge, eds. CAB International, Wallingford, UK.

Inserra, R. N., Duncan, L. W., Troccoli, A., Dunn, D., Dos Santos, J. M., Kaplan, D., and Vovlas, N. 2001. Pratylenchus jaehni sp. n. from citrus in Brazil and its relationship with $P$. coffeae and P. loosi (Nematoda: Pratylenchidae). Nematology 3:653-665.

Jassogne, L., Van Asten, P. J. A., Wanyama, I., and Baret, P. V. 2013. Perceptions and outlook on intercropping coffee with banana as an opportunity for smallholder coffee farmers in Uganda. Int. J. Agric. Sustain. 11: 144-158.

Jones, J. T., Haegeman, A., Danchin, E. G. J., Gaur, H. S., Helder, J., Jones, M. G. K., Kikuchi, T., Manzanilla-Lopez, R., Palomares-Rius, J. E., Wesemael, W. M. L., and Perry, R. N. 2013. Top 10 plant parasitic nematodes in molecular plant pathology. Mol. Plant Pathol. 14:946-961.

Jones, M. G. K., and Fosu-Nyarko, J. 2014. Molecular biology of root lesion nematodes (Pratylenchus spp.) and their interaction with host plants. Ann. Appl. Biol. 164:163-181.

Lordello, L. G. E. 1982. Nova ocorrencia do nematoide Meloidogyne hapla em cafeeiro. Rev. Agric. (Piracicaba) 57:6

Machado, A. C. Z., Ferraz, L. C. C. B., and Oliveira, C. M. G. 2007. Development of a species-specific reverse primer for the molecular diagnostic of Pratylenchus brachyurus. Nematropica 37:249-257.

Manzanilla-Lopez, R. 2012. Methodology and symtomatology. Pages 89-127 in: Practical Plant Nematology. R. Manzanilla-Lopez and N. Marban-Mendoza, eds. Editorial Colegio de Postgraduados, Texcoco, Mexico pages 89-127.

Mekete, T., Sikora, R. A., Kiewnick, S., and Hallmann, J. 2008. Plant-parasitic nematodes associated with coffee (Coffea arabica 1., rubiaceae) in Ethiopia. Nematropica 38:177-186

Meng, Q. P., Long, H., and Xu, J. H. 2004. PCR assays for rapid and sensitive identification of three major root-knot nematodes, Meloidogyne incognita, M. javanica and M. arenaria. Acta Phytopathol. Sin. 34: 204-210.

Muniz, M. de F. S., Campos, V. P., Castagnone-Sereno, P., Castro, J. M. de C. E., Almeida, M. R. A., and Carneiro, R. M. D. G. 2008. Diversity of Meloidogyne exigua (Tylenchida: Meloidogynidae) populations from coffee and rubber tree. Nematology 10:897-910.

Nježić, B., De Sutter, N., and Moens, M. 2014. Interaction of Tagetes patula cv. Single Gold with the life cycle of the plant-parasitic nematodes Meloidogyne chitwoodi and Pratylenchus penetrans. Russ. J. Nematol. 22: 101-108.

Nyczepir, A. P. 2009. Dynamics of concomitant populations of Pratylenchus vulnus and Meloidogyne incognita on peach. Nematropica 39:273-279.

Oliveira, C. M. G., Inomoto, M. M., Vieira, A. M. C., and Monteiro, A. R. 1999. Efeito de Densidades Populacionais de Pratylenchus brachyurus no crescimento de plantulas de Coffea arabica cv. Mundo Novo e C. canephora cv. Apoata. Nematropica 29:215-221.

Pang, W., Hafez, S. L., and Sundararaj, P. 2009. Concomitant interaction of Pratylenchus penetrans and Meloidogyne hapla on onion. Nematropica 39: 297-303.

Randig, O., Bongiovanni, M., Carneiro, R. M. D. G., and Castagnone-Sereno, P. 2002. Genetic diversity of root-knot nematodes from Brazil and development of SCAR markers specific for the coffee-damaging species. Genome 45:862-870

Ravindran, A., Kumar, A., Antony, D., and Eapen, S. J. 2011. Single tube duplex PCR for simultaneous detection of Phytophthora capsici and Radopholus similis infecting black pepper (Piper nigrum). Indian Phytopathol. 64:353-357.

Rodrigues, I., and Crozzoli, R. 1995. Efectos de nematodos agallador Meloidogyne exigua sobre el crecimiento de plantas de café en vivero. Nematol. Mediterr. 23:325-328.

Rodriguez-Kabana, R., and Pope, M. H. 1981. A simple incubation method for the extraction of nematodes from soil. Nematropica 11:175-185.

Salgado, S. M. L., Guimarães, N. M. R. B., Botelho, C. E., Tassone, G. A. T., Marcelo, A. L., Souza, S. R., Oliveira, R. D. L., and Ferreira, D. F. 2015. Meloidogyne paranaensis and Meloidogyne exigua in coffee plantations from the south of Minas Gerais state. Coffee Sci. 10:475-481. 
Sirias, H. and Cristina, I. 2011. Root-knot nematodes and coffee in Nicaragua: Management systems, species identification and genetic diversity. Thesis. Acta Univ. Agric. Sueciae.

Stanton, J. M., McNicol, C. D., and Steele, V. 1998. Non-manual lysis of second-stage Meloidogyne juveniles for identification of pure and mixed samples based on the polymerase chain reaction. Australas. Plant Pathol. 27:112-115.

Terazono, E. 2017. Struggling Brazilian coffee farmers turn to pepper. Financial Times, Agricultural Commodities.

Thuy, T. T. T., Yen, N. T., Tuyet, N. T. A., Te, L. L., and De Waele, D. 2012. Plant-parasitic nematodes and yellowing of leaves associated with black pepper plants in Vietnam. Arch. Phytopathol. Plant Prot. 45:1183-1200.

Toyota, K., Shirakashi, T., Sato, E., Wada, S., and Min, Y. Y. 2008. Development of a real-time PCR method for the potato-cyst nematode Globodera rostochiensis and the root-knot nematode Meloidogyne incognita. Soil Sci. Plant Nutr. 54:72-76.

Trinh, P. Q., De La Pena, E., Nguyen, C. N., Nguyen, H. X., and Moens, M. 2009. Plant-parasitic nematodes associated with coffee in Vietnam. Russ. J. Nematol. 17:73-82.

Trinh, P. Q., Waeyenberge, L., Nguyen, C. N., and Moens, M. 2012. Morphological and molecular diversity of Radopholus on coffee in Vietnam and description of $R$. daklakensis sp. n. from Robusta coffee. Nematology 14:65-83.

Trinh, P. Q., Wesemael, W. M. L., Nguyen, S. T. T., Nguyen, C. N., and Moens, M. 2011. Pathogenicity and reproductive fitness of Pratylenchus coffeae and Radopholus arabocoffeae on Arabica coffee seedlings (Coffea arabica cv. Catimor) in Vietnam. Eur. J. Plant Pathol. 130:45-57.

Trudgill, D. L., and Blok, V. C. 2001. Apomictic, polyphagous root-knot nematodes: Exceptionally successful and damaging biotrophic root pathogens. Annu. Rev. Phytopathol. 39:53-77.

Tuminem, Supramana, Sinaga, M. S., and Giyanto. 2015. First report on the root knot nematodes Meloidogyne spp. of sweetpotatoes in Sorong Regency, West Papua Indonesia. Int. J. Sci. Basic Appl. Res, 21:325-334.

Uehara, T., Mizukubo, T., Kushida, A., and Momota, Y. 1998. Identification of Pratylenchus coffeae and P. loosi using specific primers for PCR amplification of ribosomal DNA. Nematologica 44:357-368.

Umesh, K. C., Ferris, H., and Bayer, D. E. 1994. Competition between the Plant-Parasitic Nematodes Pratylenchus neglectus and Meloidogyne chitwoodi. J. Nematol. 26:286-295.
Villain, L. 2008. Economica importance, epidomiology and management of Pratylenchus sp. In coffee plantations. Pages 65-84 in: Plant-Parasitic Nematodes of Coffee. R. Souza, ed. Springer Science+Business Media B.V., Dordrecht.

Villain, L., Sarah, J. L., Hernandez, A., Bertrand, B., Anthony, F., Lashermes, P., Charmetant, P., Anzueto, F., and Carneiro, R. M. D. G. 2013. Diversity of root-knot nematodes parasitizing coffee in Central America. Nematropica 43:194-206.

Vovlas, N., and Di Vito, M. 1991. Effect of root-knot nematodes Meloidogyne incognita and $M$. javanica on the growth of coffee (Coffea arabica L.) in pots. Nematol. Mediterr. 19:253-258.

Waeyenberge, L., Ryss, A., Moens, M., Pinochet, J., and Vrain, T. C. 2000. Molecular characterisation of 18 Pratylenchus species using rDNA restriction fragment length polymorphism. Nematology 2:135-142.

Wang, K. H., and McSorley, R. 2008. Exposure time to lethal temperatures for Meloidogyne incognita suppression and its implication for soil solarization. J. Nematol. 40:7-12.

Watanabe, T., Masumura, H., Kioka, Y., Noguchi, K., Min, Y. Y., Murakami, R., and Toyota, K. 2013. Development of a direct quantitative detection method for Meloidogyne incognita and M. hapla in andosol and analysis of relationship between the initial population of Meloidogyne spp. and yield of eggplant in an andosol. Jpn. J. Nematol. 43:21-29.

Whitehead, A. G., and Hemming, J. R. 1965. A comparison of some quantitative methods of extracting small vermiform nematodes from soil. Ann. Appl. Biol. 55:25-38.

Wiryadiputra, S. T. 2008. Indonesia and Vietnam. Pages 277-292 in: Plant-Parasitic Nematodes of Coffee. R. Souza, ed. Springer Science+Business Media B.V., Dordrecht.

Wishart, J., Phillips, M. S., and Blok, V. C. 2002. Ribosomal intergenic spacer: A polymerase chain reaction diagnostic for Meloidogyne chitwoodi, M. fallax, and M. hapla. Phytopathology 92:884-892.

Yan, G. P., Smiley, R. W., and Okubara, P. A. 2012. Detection and quantification of Pratylenchus thornei in DNA extracted from soil using real-time PCR. Phytopathology 102:14-22.

Zijlstra, C., Donkers-Venne, D. T. H. M., and Fargette, M. 2000. Identification of Meloidogyne incognita, $M$. javanica and $M$. arenaria using sequence characterised amplified region (SCAR) based PCR assays. Nematology 2: 847-853. 